https://doi.org/10.15407/ufm.21.02.274

L.Ya. ROPYAK ${ }^{1, *}$, T.O. PRYHOROVSKA ${ }^{1, * *}$, and K.H. LEVCHUK ${ }^{2}$

1 Ivano-Frankivsk National Technical University of Oil and Gas,

15 Karpatska Str.,

UA-07600 Ivano-Frankivsk, Ukraine

${ }^{2}$ G.V. Kurdyumov Institute for Metal Physics of the NAS of Ukraine,

36 Academician Vernadsky Blvd., UA-03 142 Kyiv, Ukraine

*1_ropjak@ukr.net, ** pryhorovska@gmail.com

\title{
ANALYSIS OF MATERIALS \\ AND MODERN TECHNOLOCIES FOR PDC DRILL BIT MANUFACTURING
}

\begin{abstract}
The article presents a review of PDC (polycrystalline diamond composite) drill bit manufacturing technologies and used metals in order to provide surface quality and accuracy as well as to attract a wider range of scientists to find new technologies and improve current ones in the field of oil and gas production. The review deals with studies of mechanical and physical characteristics, properties, structure effects as well as modern PDC drill bit manufacturing technologies, tools and technical means. Authors discuss the main tendencies and analyse differences in the technologies determined by the used metals. A drill bit quality assurance diagram is developed, which depicts drill bit quality as a complex indicator determined by both used metals and drill bit element-manufacturing technologies. The follow technological stages are defined as the drill bit quality assurance stages: workpieces production, rough and semi-rough machining, chemical and thermal treatment, body covering, finishing machining, cutter soldering and drill bit assembling. As stressed, the used metals determine not only drill bit manufacturing technology, but also drill bit design.
\end{abstract}

Keywords: PDC drill bit, quality, technology, metal, welding, casting, body, cutter.

\section{Introduction}

Drill bits are widely used for oil, gas and water drilling, as well as in mining and exploration. Their main performance options are mechanical speed, stability and penetration. The current drill bit market stipulates

Citation: L.Ya. Ropyak, T.O. Pryhorovska, and K.H. Levchuk, Analysis of Materials and Modern Technologies for PDC Drill Bit Manufacturing, Progress in Physics of Metals, 21, No. 2: 274-301 (2020) 
scientific, design and technological development due to high competition of the manufacturers in different countries. The drill bits' design, manufacturing, and performance problems are in the focus of the national program of fuel provision 'Energy Strategy of Ukraine until 2035' [1] aims at prospecting and exploration drilling increasing.

Currently, the polycrystalline diamond composite (PDC) drill bits are used for oil, gas, and water drilling and drive three-cone bits out from the drilling market due to design benefits. Absence of a bearing assembly and movable elements in the PDC drill bit design provides increasing of rate of penetration, low number of lifting operations, repairable design, and due to this fact higher mechanical speed, lower costs per a penetrated meter, and well completion time with collector properties of the productive horizon.

This way, scientific and technological progress and modern drilling requirements stipulate for new designs and technologies of drilling tools. Drill bits are the most loaded structures due to complex bottomhole kinematics, limited wellbore space, high temperatures, high static and dynamic pressures, associated with liquid column and high pressure fluctuations in bits' hydraulic elements, and huge dynamic loads associated with rock destruction of different hardness and abrasiveness.

Exploration and well production increasing, difficult operational conditions as well as serious drilling manufacture competition put forward a claim of quality, efficiency and value of modern drilling tools.

The drill bit quality indicators are the issues at stake. Traditionally performance indicators specify drill bit quality, in particular reliability and operating time [2]. This means that scientists determine quality through cutter operation indicators [3], because there are no clear relations between drill bit options and drilling indicators. This spawns complexity of drilling indicator forecasting (rate of penetration, operational time, average speed of mechanical drilling in meters per hour, etc.) $[4,5]$.

On the other hand, focusing on rock destruction indicators [6] often disregards drill bit technology issued (drill body technology, covering, cutter attaching, metals, etc.) Besides, some issues are still challenged, in particular a comprehensive review of metals from the standpoint of metal physics, physical metallurgy, technical means and equipment designs used for PDC drill bit manufacturing.

This review focuses our attention on the metals and technologies used for PDC drill bit manufacturing, summarizing the main features of this process refer to metals and technologies, national and international experience of PDC drill bit usage analyzation and comparing as well as drill bit quality model development. 


\section{Modern Technologies of PDC Drill Bit Manufacturing}

\subsection{Main Directions of Technology and Material Improvement for Drill Bit Durability Increasing}

Technological, design and operation method are used in order to increase drill bit durability. The authors start review of drill bit durability and efficiency improvement approaches from studying works aimed at dynamic loading decreasing within drill bit operation.

The works simulated friction contact in shell-core systems under nonmonotonic loading in order to specify the rigidity [7-9] and the damping ability [10-13] of shell anti-vibration devices.

Rod system static and dynamics with interaction of elastic or inelastic medium lateral surface were studied refer to issues of drill string sticking [14-16], safe operation of oil and gas equipment in difficult mining and geological conditions [17-19], drill string durability [20, 21], and drill string stabilization [22-24].

Special anti-vibration and damping devices reduce drill string vibrations to optimize drill bit operation modes [25-27]. The works [28-31] present theoretical and experimental studies of strength, rigidity, damping characteristics and rational design of the aforementioned devices.

The work [32] analyses in detail the drilling equipment design and technology of stuck metal drill string releasing. The authors also developed a dynamic mathematical model that takes into account elastic oscillations of drilling pipes coupled to a shock mechanism to make possible improvement of engineering methods of drill tubes modelling and calculations at the stage of their design and production [33].

The paper [34] presents a mathematical model of drill string operation with a surface vibration mechanism, which releases the stuck drill. Besides, the authors developed a discrete-continual model taking into account wave propagations in drill strings with sequentially fitted different pipes (metal, cross-sectional area, external loads), provided numerical calculation of the main kinematic and dynamic characteristics of the studied system, and developed recommendations on forced oscillation amplitudes to specify resonant frequencies for stuck drill string realizing and sticking destruction.

Authors of Ref. [35] studied a contact of metal drill string made of different metals with the bottomhole. The authors developed a mathematical model to analyse the strength properties of shock-loaded metal pipes, obtained an analytical solution of the dynamic problem of elastic oscillations of stuck drill string with a built-in impact mechanism. Besides, the authors numerically simulated and estimated strength of the stuck drill string, taking into account the elastic and plastic properties of metals, and provided recommendations for the selection of metals for drilling pipes. 
Generally, material scientists focus their efforts on life increasing of details and drill bits as well as methods of deformation definition [36]. Thus, Ref. [37] proposed to increase an aluminium drill pipes' life by applying a protective thickening of the optimum shape to provide stability under axial force loading and torque. The article [38] proposed to increase the wear resistance of steel bits' details by their surface centrifugal reinforcement with tungsten carbide during manufacturing a workpiece with two mutually perpendicular axes of mould rotation. Tests of reinforced parts for wear are described in Ref. [39].

Application of one-layer [40] and two-layer coatings [41] is an approach to increase drilling tool longevity. In order to make a rational choice of coatings, their physical and mechanical characteristics are studied. In particular, a series of studies is devoted to the structure and properties of layered coatings from the point of view of the solid-state physics [42-46] and electrochemistry [47-49].

The authors studied some aspects of surface hardening by electrosparking [50, 51] and high-speed milling [52], chemical treatment [53, 54], and high-temperature pressing [55] of details made of alloys.

Authors of Refs. [56-59] studied the load-bearing capacity of twolayer coatings under the local arbitrarily oriented loading. The authors studied a layer thickness ratio for the two-layer coating of the aluminium-aluminium oxide system to provide the maximum bearing capacity of the steel-based composition. A one-dimensional model of the interaction of a thin coating with particles of fixed and unattached abrasive was proposed in [60].

One of the promising methods of coating is electrochemical chromium plating of steel parts in a flow electrolyte [61]. The technological parameters of the coating process were optimized to ensure maximum microhardness and minimum conicalness of cylindrical parts.

There were developed models to study the effect of flexible coatings on the strength of thin-walled structures with crack-like defects. In particular, the papers [62-64] investigated the stress concentration in defective coating plates, and in publications [65-67] similar problems are solved for coated shells.

The authors proposed computational models for the treatment of crack defects by injection of compliant metals [68-70] or non-contrasting filler [71, 72].

Nowadays, there are the following directions of drill bit technology improvement [73-75]:

- efficiency of metals and their impact on drilling tool performance;

- study of new coating effectiveness and surface treatment methods;

- investigation of contact interaction of drilling equipment elements in order to specify tolerances of details; 
- study of stress state and performance of the drilling equipment elements, including the finite element method;

- study of complex shaped workpiece quality.

At the same time, certain issues are still challenged; particularly, there is no review of available metals, technical means, and structures of mechanisms used for PDC drill bits, and no comprehensive universal technology of providing accuracy and quality of production of the aforementioned drill bits.

\subsection{PDC Drill Bit Design Features and Main Stages of Drill Bit Manufacturing}

PDC drill bits (polycrystalline diamond bits) are high-tech product and used for water, oil/gas wells or geothermal well drilling. PDC drill bits are made of high quality steel, solid alloys and are equipped with diamond polycrystalline cutters. The size and number of cutters depend on the number of blades and the bits' diameter. The PDC drill bits have high wear resistance and provide high speeds of penetration (2-3 times higher than 3-cone drill bits). Figure 1 shows the PDC drill bit design [76].

The outer diameter is the main dimension of the drill bit for oil and gas drilling, and ranged as follows: $120.6 \mathrm{~mm} ; 124.0 \mathrm{~mm} ; 142.9 \mathrm{~mm}$; $149.2 \mathrm{~mm} ; 155.6 \mathrm{~mm} ; 215.9 \mathrm{~mm} ; 295.3 \mathrm{~mm} ; 393.7 \mathrm{~mm}$; and $444.5 \mathrm{~mm}$. This size range was specified by API and IADC, state standards (GOSTs and DSRUs), and drilling regulations, which refer to well construction
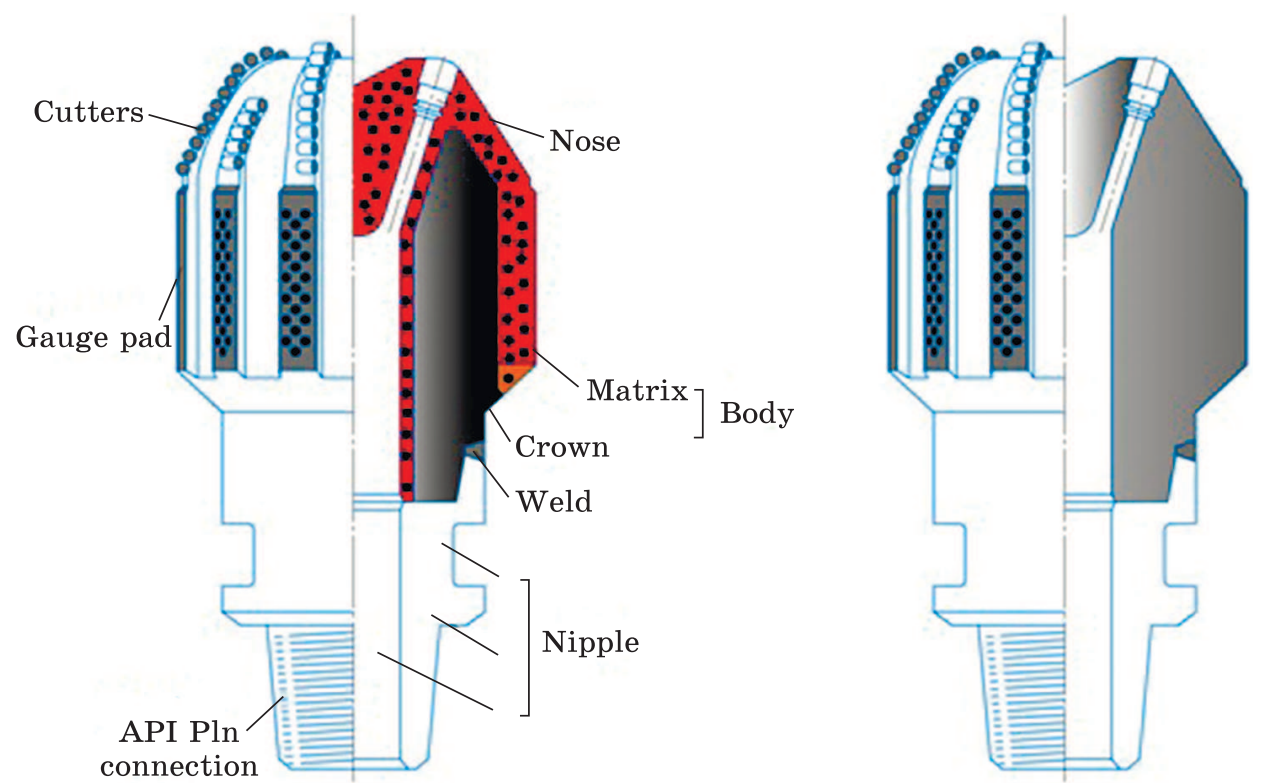

Fig. 1. Matrix and steel drill bit designs (Hudges Christensen materials) [76] 
and dimensions of other drilling equipment, namely, diameters of downhole engines and turbodrills, casings, tools for carrying out lifting operations, emergency and other types of work.

The PDC drill bits have a body (solid or with welded blades depending on the used metal), blades with brazed cutters made of super hard alloys and polycrystalline diamond cutting plates. PDC drill bit technology is divided into the following main stages:

- manufacturing of a nipple, a body and blades (with holes for cutters) workpieces;

- manufacturing of cutters;

- brazing of cutters into the drill bit workpiece;

- bit assembling (blades with cutters-case-nipple).

\subsection{Technologies and Material Used for Body Workpieces}

Bodies for PDC drill bits are made of two types: assembled and solid ones. This way, solid bodies are made of the same metal (by hard alloy agglomeration or by steel casting, forging or stamping); assembled bodies are made of two different metals and then threaded and welded. Accordingly, technologies of their manufacturing differ (Fig. 2).

As it was mentioned above, solid bodies are made by hard alloy agglomeration or by steel casting. In this case, solid body technology provides manufacturing of bodies with blades with and without cutters. The article [77] presents a high temperature and pressure technology (pressure up to $1.5 \mathrm{GPa}$ and temperature up to $1250{ }^{\circ} \mathrm{C}$ ) to manufacture bit bodies with a diameter up to $212 \mathrm{~mm}$ by a reusable high-pressure chamber. The technology envisages the solid body agglomeration with and without cutters, which in their turn includes or does not include heat-resistant PDC-plates. The technology restricts the PDC-plate materials: only heat-resistant materials as 'carbonado' can be used.

Bodies of PDC drill bit can be assembled; the body is threaded to the hardened steel nipple of the bit. The nipple design provides the threaded connected surface to be coupled with drill pipes. In this case, the body workpiece is manufactured by steel casting or by hard alloy agglomeration). Figure 1 shows a body assembling diagram.

Manufacturers out of Ukraine make, mainly, solid bodies (so-called matrix drill bits). The body consists of two parts: a crown ring and a crown. As far as hard alloy are relatively rigid and are difficult to machinate, the crown ring is used to attach the bit body to the neck of the bit. Traditionally, matrix bodies are made by casting in graphite moulds. Cavities in graphite moulds are typically processed via the CNC (computer numerical control) machines. Then, cavities are threated manually to design specific structural features. This may require additional clay packing to provide desired configuration of some structural 


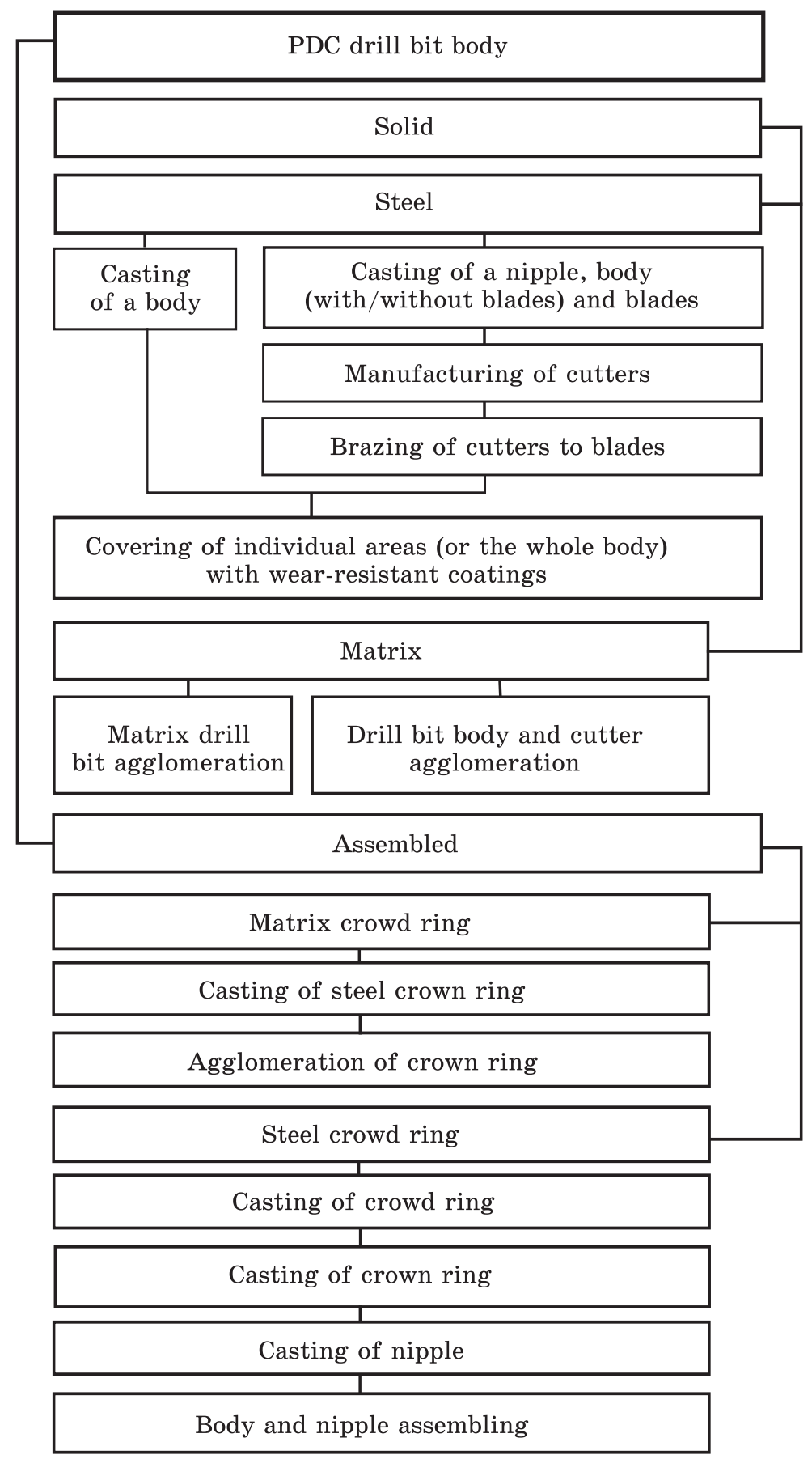

Fig. 2. PDC drill bit case manufacturing generalized technology (developed by the authors) 
elements of the body. If necessary, pre-fabricated elements or inserts (ceramic, graphite or sand-filled rubber-coated components) may be used. These inserts are placed inside the mould to specify inner grooves, pockets for cutters, holes in the body for removal of drilling mud as well as other external structural elements. Then, graphite moulds are filled with hard alloy powder: tungsten carbide particles, titanium carbide, tantalum carbide, etc.

The next stage is assembling the pre-made crown ring inside the mould in a specific place and in the desired position. The crown ring is usually at least partially immersed in the environment of solid carbide particles inside the mould. The mould is further subjected to vibration, or the particles can be packaged in any other way to increase the den-

Table 1. Main stages of PDC drill bit case manufacturing [76]

\begin{tabular}{|l|l|}
\hline \multicolumn{1}{|c|}{ Stage title } & \multicolumn{1}{c|}{ Carried out actions } \\
\hline $\begin{array}{l}\text { Graphite } \\
\text { mould } \\
\text { devel-op- } \\
\text { ment }\end{array}$ & $\begin{array}{l}\text { Graphite mould development for the drill bit } \\
\text { body is the first stage of PDC drill bit manufac- } \\
\text { turing. The internal part of the cylinder mould is } \\
\text { formed on the lathe, forming an imprint profile } \\
\text { of the bit cutting part }\end{array}$ \\
$\begin{array}{l}\text { Milling of } \\
\text { holes for } \\
\text { cutters }\end{array}$ & $\begin{array}{l}\text { Holes for PDC cutters are milled on a CNC ma- } \\
\text { chine to specify the location and direction of the } \\
\text { holes }\end{array}$ \\
$\begin{array}{l}\text { Graphite } \\
\text { inserts }\end{array}$ & $\begin{array}{l}\text { Graphite inserts are glued into the holes just } \\
\text { made. These graphite inserts form the sockets } \\
\text { for the cutters when forming the matrix cutting } \\
\text { part of the bit }\end{array}$ \\
$\begin{array}{l}\text { Loading } \\
\text { into a heat } \\
\text { furnace } \\
\text { ing result }\end{array}$ & $\begin{array}{l}\text { The steel workpiece is placed in a mould, which } \\
\text { then is filled with tungsten carbide. The steel } \\
\text { workpiece is preheated to burn any impurities. } \\
\text { After pre-heating, brass and liquid additive sub- } \\
\text { stance is added to the assembly prior to loading } \\
\text { the entire structure into a heat furnace } \\
\text { The obtained PDC drill bit workpiece is finished } \\
\text { for practical use }\end{array}$ \\
\hline
\end{tabular}


sity of the metal. Further, the solids particles are poured with molten copper-based binder. The casting mould and the body are cooled to solidify the binder material. The crown ring is attached to the formed crown, and all inserts are removed from the mould. After body removing from the mould, it is fixed to the nipple. As noted above, body metal is relatively solid and difficult to machinate; the crown ring is used to attach the body to the nipple. The crowd ring can have threaded surface to join the body to the nipple. After connection the nipple to the body, these parts are welded [78]. Figure 2 and Table 1 present a drill bit body manufacturing scheme.

Matrix drill bits are better in terms of erosion and wear resistance than steel bit. This way, matrix drill bits provide higher rate of penetration per the drill bit and better controllability of the bit, taking into account possible multiple reusability through restoration.

However, usage of matrix metal for entire body is disadvantageous, since abrasive wearing is characteristic only of certain sections. Therefore, the majority of modern drill bits are made of corrosion and abrasion resistant steels, with treatment or strengthening of certain sections.

Manufactures in Ukraine use heat resistant steel 25G2S2N2MA [79] to make steel bodies. Double tempering with accelerated cooling is used to improve the toughness [80]. Moreover, Ukrainian manufactures make drill bit bodies both with blades and with welded blades to bodies [81].

Abrasive wear of near-cutter areas is a significant problem for steel bodies of drill bits. Besides, this problem is acute for braze filling that keeps cutters from tearing out, provides exposure, increases protection area near cutters. In turn, the abrasive wear of cutters causes decreasing of specific pressure on the rock within its cutting, and rate of penetration decreasing. In order to increase abrasion resistance, manufactures reinforce near-cutter areas or use a protective wear-resistant coating.

Thus, the articles $[78,82]$ suggest using a solid hard alloy covering to improve the resilience of the prefabricated steel body. The authors developed a method of arc surfacing to provide the following advantages: possibility to change metal properties and to apply cover to the surface with both thin (up to $0.3 \mathrm{~mm}$ ) and thick (up to $5 \mathrm{~mm}$ ) layers. This method bases on electrode usage for arc surfacing, made of VK20KS, VK15C, VK8 and TN 20 powders, regenerated by vibrating grinding. Further, these coatings should be machined, for example by cutters made of materials Elbor-R, ASPC, SVBN-1, SVBN-5B.

In order to cover some areas of steel bodies by arc surfacing, the coating is heated by electrodes made of Tero-Cote 7888t, Diamax M, relay LZ-11-7 (derived from tungsten carbides) [83]. The authors stated random resilience proprieties of composite hard alloy covering LZ-11-7 and Diamax M, consisting of reinforcing Fe-basis particles (submerged spherical and crushed tungsten carbides). The TeroCote $7888 \mathrm{t}$ Ni-based 
composite hard alloy covering provides effective protection under conditions of water-abrasive wear. The Tero-Cote7888t protective coating exceeds the wear resistance of the LZ-11-7 and Diamax M relays by 1.5 and 2.0 times respectively.

The article [84] proposes to reinforce some areas of drill bit body by multilayer facing, and the first and second layers are differ from each other in carbide content and thickness. Another method of coating is spraying, as described in Ref. [85]. The authors suggested spraying a pre-coating layer and stable protective facing layer on the drill bit body surface. The pre-coating layer hardness is less than the deposited protective hardcover hardness, but more higher than the hardness of the drill bit body. The deposited protective layers' thickness is from 0.3 to $0.8 \mathrm{~mm}$.

Similar methods are used to restore the most worn areas of drill bits, for example, holes for cutters.

The assembling of the drill bit body and the nipple is another technological problem. The nipple design provides two types of threads: metric and tube joint threads. The tube joint thread joints the nipple and the drill string. The metric thread joints the drill bit body and the nipple; further, these details are welded. The quality of the joint is determined by the alignment of body and nipple axis at the stages of positioning of these details within assembling and fixing their mutual position by welding. Welding causes thermal deformations of the nipple and the body, which displace and/or distort the body and nipple positions. If the deformation exceeds the tolerance value, the whole drill bit is considered unfit for use. Technology provides high quality of thread machining (accuracy grade 6) [82], but even this does not provide the necessary precision of the joint after welding. Drill bit operation statistics shows that accuracy of the 'body-nipple' relative position (axis incompatibility and misalignment) of significantly affects the drill bit performance. Significant axe skew leads to uneven cutter wear, and in its turn, drill bit life reduces by several times. In this case, cutter wear is uneven and the cutter can fall out, while the other blade is in working order. The 'body-nipple' axe skew obtained after welding, affects the drill bit controllability during drilling, and cause well axe deviation from the planned trajectory. Thermal deformations significantly change the 'body-nipple' magnitude of the radial deflection, indicating significant lacks of existing assembling technology.

Traditional (factory) welding technology has the following operations:

- joint the body and the nipple by the metric thread until they lock;

- provide three tack welds evenly in a circle;

- weld the body and the nipple.

The disadvantages of technology are the following:

- tack weld positions are random; 
- tack weld can be started from anywhere;

- bypass direction of welding is not regulated.

Experiments [86] showed that tack welds cause the 'body-nipple' axe deviation in the direction opposite to the tack weld. As the temperature decreases, the body starts to deviate in the opposite direction, and after cooling, the body shifts towards the weld. As the thermal deformation vector in the weld joint is always directed towards the tack weld, the authors proposed to correct the relative position of the details by selecting the positions of a new weld and compensating the offset axes of the welded details. Every new tack weld provides a consistent approximation of the body and the nipple axes. Thus, tack welds are positioned specifically for every drill bit. The position of every next tack weld is defined after evaluating the previous effect.

The next technological step is thread machining on the bit nipple. This operation is machined either by a lathe or by a CNC machine. In the first case, the cams rigidly fix the drill bit. The three-jaw chuck has axes that coincide with the axis of the welded body. To avoid the possible drill bit position deviation within thread machining, conical surface of the thread is machined at the same CNC. The conical surface of the nipple is coaxial to the body and chuck axes. Thereafter, a conical pin of the lathe tailstock is introduced into the surface of the central hole to the rigid touch. The pin is coaxial to the chuck axe. After that, the machined conical thread is theoretically arranged coaxially with the geometric axis of the drill bit [87].

Thread machining by CNC machines [88] is provided in the standard conical thread machining approach. The following options are specified: thread end point, thread pitch, thread profile height, depth, the smallest diameter for thread, and relative $x$-coordinate of the cutter exit point. The required number of passes for thread machining is automatically determined by the control system as the closest integer from dividing the height of the profile to the cutting depth.

The issues of machining are discussed in Ref. [89]. The authors studied change of a thread lead angle and proposed a method to specify the conical thread lead line. They calculated conical thread lead lines for oil/gas pipes using different relations and specified related errors. The authors showed that thread lead angle changes more intensively for conical threads of small diameters, but slightly for conical threads of big diameters. The authors stated that increasing of the thread lead angle leads to increasing of the helical line angle.

Researchers have also proposed a tool thread hardening [90]. They proposed a cutter for high-performance machining of an external triangular cylindrical thread of increased accuracy. It has a handle and a cutting part with left and right rectangular cutting edges and a radial cutting edge between them. The anterior angle of the cutter is non-zero 
Fig. 3. Two-thread rolling tangential head [78]: 1 - rollers, 2 - workpiece, 3 - body head, 4 - holder

and can be both positive and negative. The cutting edge profile is not equal to the angle of the thread profile to be cut by the cutter. The

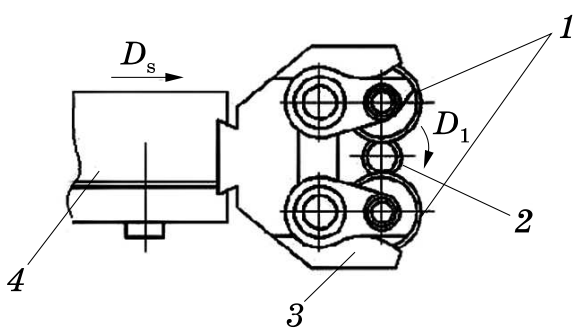
cutting edge profile is specified by the geometrical parameters of the cutting. The technical result is achieved by improving the thread machining precision.

Thread for nipples of $65-70 \mathrm{~mm}$ diameter can be rolled through CNC machine using a tangential threaded head, instead of cutting (Fig. 3). The tangential threaded head is mounted in one of the positions of the multi-position revolving head of the machine or on the transverse support of the machine. Then, the tangential threaded head is moved in the transverse direction to the drill bit workpiece mounted on a rotating spindle. The method of thread rolling has the following advantage: it provides fully automatization of the high-quality thread rolling with effectively integrating it with other types of machining at the same CNC-machine.

The tangential threaded double-roller head has two rollers with parallel arrangement of axes, which rotate due to friction interaction with the forcibly rotated workpiece. Roller top threads should be placed exactly one opposite to the other. The roller head is moved in parallel to the workpiece surface. Rolling stops when the axes of the rollers and the workpiece get positions in the same plane. The length of the rolled thread does not exceed the width of the rollers. The roller multi-start thread direction is opposite to the workpiece thread direction. The 'workpiece-rollers' direction synchronization is provided in two ways: (1) by additional structural elements; and (2) independent rotation of the rollers, when the kinematic connection is established directly at working due to the axial self-alignment of one of the rollers.

For the last case, there may be a misalignment of roller threads, which is the cause of the defect. The duration of the rolling cycle does not exceed $6 \mathrm{~s}$. The thread rolling improves the efficiency of this operation, but also the quality of the thread obtained. The thread surface obtained by rolling has bigger strength and reliability, which is especially relevant for the drill bit due to significant torques and alternating cyclic axial forces. The thread rolling provides thread surface microhardness increasing from 13 to $33 \%$ for alloy and structural steels, and cold hardening depth is $0.4 \mathrm{~mm}$ [77].

Therefore, to sum it up, we can consider (1) technological characteristics of the drill bit body is indicated by its resistance to wear in cor- 
rosive and abrasive media, and (2) studies focuses, mainly, on wear resistance increasing and manufacturing cheapening.

\subsection{Technologies and Materials for PDC Cutter Manufacturing}

Plates for modern PDC cutters are produced in different configurations, but the most widespread are the round and oval ones. Until recently, the most widely used PDC cutters were cylindrical or cylindrical cutters with a work surface that is oriented at an angle to the axis (Fig. 4). The elongated cutter provides better PDC plate wear and erosion resistance, and increased strength within brazing the PDC plate to the cutter. Round plates are made with diameters of 8, 13, and $19 \mathrm{~mm}$. Schlumberger Company also produces 11 and $16 \mathrm{~mm}$ diameter plates. The V.M. Bakul Institute for Superhard Materials of the NAS of Ukraine produces plates of only $13.5 \mathrm{~mm}$ diameter plates.

Oval-shaped plates are used for drilling both soft and hard rocks, since their area is $\mathbf{4 0} \%$ larger than similar circular shapes, and they provide maximum load at the rock-cutter contact, which will increase the cutting depth (according to BBL Downhole Tools Ltd).

The sizes of oval plates that are manufactured and used are $9 \times 13$, $13 \times 19$, and $19 \times 27 \mathrm{~mm}^{2}$.

The cutters are made of different diameters according to the PDC plates. The smaller diameter cutters tend to be used for drilling rocks of greater hardness. So, cutters with a diameter of $8 \mathrm{~mm}$ are used for drilling of hard rocks. The $13 \mathrm{~mm}$ PDC cutters are mostly used and intended for drilling both rocks of medium hardness and abrasive rocks. The $19 \mathrm{~mm}$ PDC cutters are used for the drilling of soft rocks. Heighted cutters are used for soft rocks, but at the same time, it is necessary to provide a better cleaning of the well bottomhole from the destroyed rock.

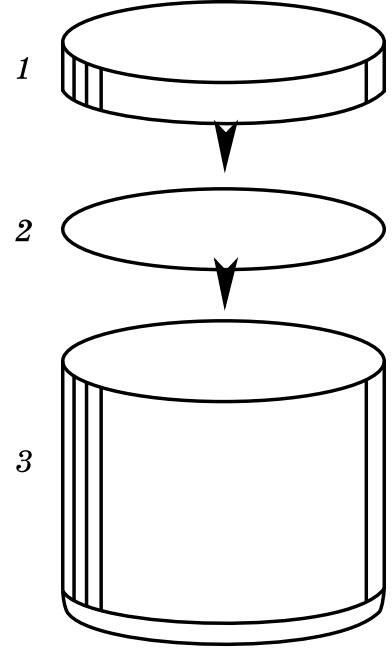

The typical PDC cutter resembles a cutter for machining (Fig. 4). The previous studies tried to draw an analogy between the machining process and the rock cutting process. Practice has shown that this approach is inappropriate and now there are oval, conical, mosaic cutters (Fig. 5).

PDC plates consist of a polycrystalline diamond layer and a super hard substrate, which are manufactured under high pressure and temperature conditions $[89,90]$. The PDC cutter provides cutting by its PDC plate (a disc of a certain

Fig. 4. PDC cutter: 1 - cutting element type $2530 \mathrm{NS}$; 2 - solid brazier 
Fig. 5. Modern PDC cutters (PDC cutter manufacture site Supreme Superhard Materials Co. Ltd)

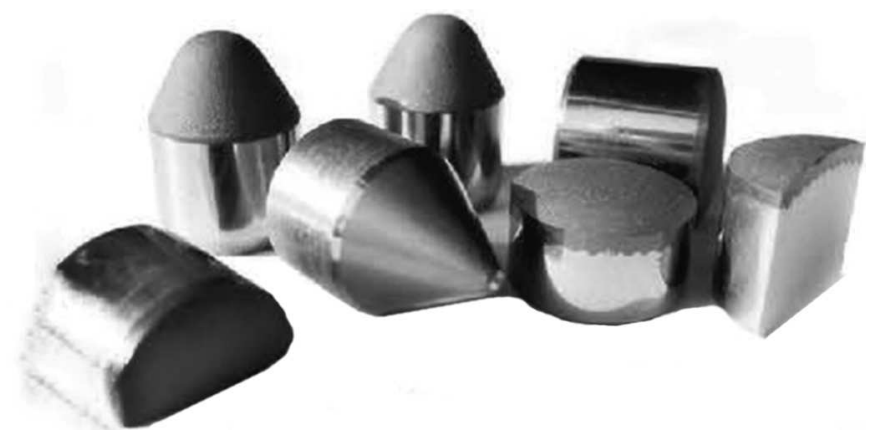

diameter), which is a layer of polycrystalline diamonds sintered in a tungsten carbide substrate at high temperatures and the pressure. PDC plates of $0.635 \mathrm{~mm}$ thickness are fixed to disks of $2.92-7.37 \mathrm{~mm}$ thickness.

The disks are brazed to the holders of various shapes, which are mounted in the drill bit body. PDC plates consist of many small chaotically arranged crystals, which provide high impact strength and wear resistance of the plate in a whole. The polycrystalline structure makes possible ever opening of new sharp edges of diamonds that effectively cut the rock. Due to this, the high mechanical speed of penetration is maintained throughout the entire operation. High durability of polycrystalline diamonds with the absence of moving elements in the PDC drill bit design contributes to the drill bit operational time.

Natural diamonds are formed in nature at pressures from 24 to 42 $\mathrm{MPa}$ and temperatures from 1000 to $3000{ }^{\circ} \mathrm{C}$. For comparison, synthetic diamonds are created at a pressure of $(7-10.5) \cdot 10^{3} \mathrm{MPa}$ and a temperature of $2000{ }^{\circ} \mathrm{C}$.

Synthetic diamonds are obtained by combining graphite with a meal solvent as nickel or cobalt (silicon may also be used). These metals act as catalysts for the synthesis of diamonds. By choosing the right pressure and temperature, different types of synthetic diamonds can be obtained. The result is a diamond powder applied to produce polycrystalline diamond compacts.

The PDC plate manufacturing begins with a careful analysis of possible impurities in the feedstock, auxiliary materials and semi-finished products used in the manufacturing. The obtained macropowders of synthetic diamonds weighed less than 500 carats are poured onto a brass deck, loaded into a furnace, heated for 19-90 min to a temperature of 450 to $500{ }^{\circ} \mathrm{C}$ and treated for $25-30 \mathrm{~min}$. Then, they are purified by saturated aqueous ammonium sulphate solution. The supersaturated ammonium powder with weight of 1 to $1.5 \mathrm{~kg}$ is placed in a two-litre glass vessel, fill with distilled cold water to $2000 \mathrm{ml}$ and stir for 10 to 15 minutes. 1000 carats of powder are placed in the vessel and fill with $2 / 3$ volume of ammonium sulphate solution. The vessel is heated on the 
hotplate for 60-70 min with constant remixing. After that, the washing is carried out with distilled water to neutral medium. The powders are dried and placed in a high-pressure chamber.

A thick hard PDC plate of $2.5 \mathrm{~mm}$ thickness is placed on a heated graphite disk. Then, $16 \mathrm{mg}$ of treated diamond powder is poured into it and then the diamond layer powder is pressing and levelling, and then PDC plate is placed on the top. The graphite disk is inserted, and the assembled container together with the heater is placed in a high-pressure furnace of the Toroid type. The container is sintered at the temperature of $2070 \mathrm{~K}$ and the pressure of $8 \mathrm{TPa}$ within $8 \mathrm{~s}$. This makes possible diamond layer percolation with cobalt from both plates (mainly from the top) and forms a sintered polycrystalline diamond layer that is firmly connected to the rigid plates. Then after cooling, they reduce the pressure and get the diamond-solid layered layer. Before the brazing, the plates are machined, and for certain types of bits, the top plate is sanded [91].

PDC plate wear resistance is tested by planning of fine-grained quartz sandstone using a special workbench. Wear resistance criteria is the wear area dimensions, which is $0.5 \mathrm{~mm}$ as standard with a planning path of $300 \mathrm{~m}$ with the following regimes: cutting depth per pass 0.5 $\mathrm{mm}$, cross feed $3.5 \mathrm{~mm} / \mathrm{sub}$. path, cutting speed $0.235 \mathrm{~m} / \mathrm{s}$ (30 paths/ $\min )$ [92].

PDC plates can be made by two-stage technology: polycrystalline layer and solid-state substrate separately agglomerated and subsequently connected [93]. A double-layer damping coating is sometimes applied to the PDC plate surface for the drilling of strong and fractured rocks [94].

In order to increase PDC plate durability, it is proposed to increase the synthetic diamond surface purity, to provide a uniform distribution of diamond grains in the plate through increasing the uniformity of their shape [95].

In addition, in order to improve PDC plate wear resistance, it is proposed as follows: [96];

- use aggregated mixtures containing from 75 to $85 \%$ strong grains

- separate solid polycrystalline aggregates, distributed in a certain way throughout the bulk [97];

- use thermostable solid areas [98] or pre-aggregated diamond-solid granules [99];

- select diamond layer components with different hardness, fracture-resistance and location [100];

- making squares, pentagons groves on the diamond layer [101].

Thus, to sum it up, we can conclude the following:

- the high cost of PDC plate manufacturing with its relatively rapid wear, determines the need for scientific research in this direction; 
- PDC plate wear resistance is determined by the quality of the bonding materials and synthetic diamonds as well as the technology of mounting the plate to the substrate and cutter;

- due to the appearance of various forms of cutters, there was a need to produce plates of corresponding complex spatial shapes;

- due to the development of various forms of PDC cutters and, accordingly, PDC plates of complex spatial forms, there was a need to ensure their secure attachment;

- wearing is the main reason for reduction of the bit diameter, so it is necessary to pay the utmost attention to the quality of the production of cutters, which are located farther from the axis of the bit.

\subsection{Technological Solutions for PDC Cutter Fixing on Drill Bit Blades}

PDC cutters are placed in the holes made in the blades, protrude above the drill bit body surface, and contact with the bottomhole. As it was mentioned above, PDC plates of cutters are made of diamond powder with the addition of a catalyst from the iron group, usually cobalt. There are many ways to attach the PDC plate to the carbide substrate of the cutter: welding, brazing with different types of hard braziers, etc. Method of PDC cutters attachment to the blades depends on the metal of the bit body (steel or hard alloy).

\subsubsection{Attachment of Cutters to the Steel Drill Bit}

Brazing technology is the preferred technology, but cutters can also be attached by using a tensioned fit. In this case, the bit body with previously drilled holes for cutters is heated in the furnace to the temperature of $440{ }^{\circ} \mathrm{C}$ to expand hole dimensions in order to freely attached cutters. When the bit is cooled to an ambient temperature, the holes are reduced in diameter, clamping the cutter in the desired position.

The PDC cutters with fixed diamond plates are mounted in blade holes by low-temperature brazier with a melting point less than $700{ }^{\circ} \mathrm{C}$. There are three thermal stability thresholds of the PDC plates depending on the diamond grade

Fig. 6. Brazed cutters (Hudges Christensen Materials)

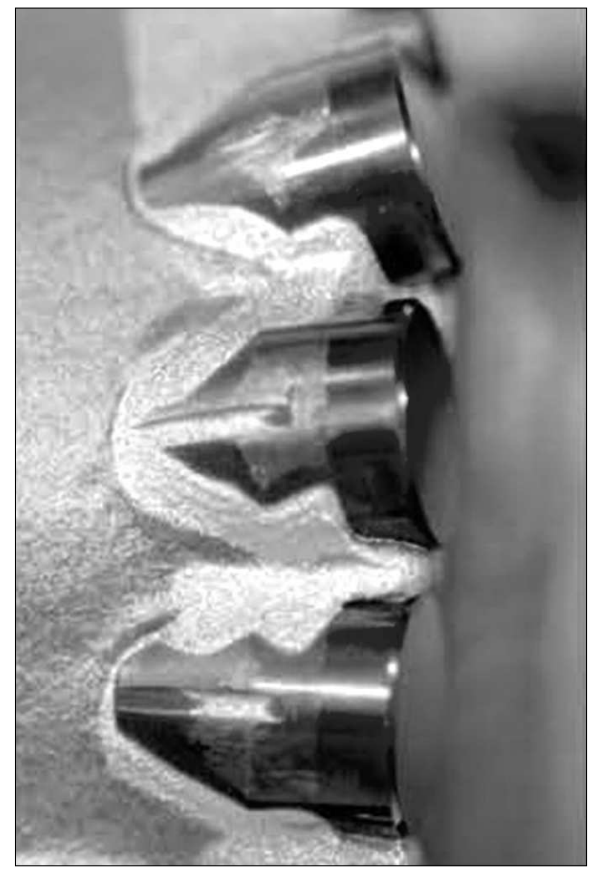


and the technology of converting it into a conglomerate during sintering and pressure: about $400{ }^{\circ} \mathrm{C}$, about $750{ }^{\circ} \mathrm{C}$ and about $1250{ }^{\circ} \mathrm{C}$. According to these temperature thres-holds, part of the diamond conglomerate cracks. This way researches in this field aim at improving of the technology to provide PDC plate thermal stability closer to $800{ }^{\circ} \mathrm{C}$ and more.

Despite the fact that brazing temperature should not exceed $800{ }^{\circ} \mathrm{C}$, heating to the temperature at $700{ }^{\circ} \mathrm{C}$ negatively affects the strength and heat resistance of PDC plates. The beyond-Ukraine manufactures use low-temperature brazing with silver hard-solder. This way cutter is attached to the substrate. Then, a thin layer of alloy is formed between the cutter and the hole (Fig. 6).

\subsubsection{Attachment of Cutters to the Matrix Drill Bit}

Holes in matrix drill bits (drill bit body is made of hard alloy agglomeration) are obtained by installing auxiliary graphite inserts, which after agglomeration are eliminated by machining. All cutters are soldered into the blades using a regular solder. Cutter handles and holes are carefully cleaned to place the brazier to the bottom of each hole. A flux is applied to cutter handlers to neutralize the oxidation products, which may interfere with the proper brazing. The flux also provides a uniform distribution of solder over the cutter. The cutters are installed into the holes and fixed with a special spring device. The drill bit body is placed in the furnace and heated to $700{ }^{\circ} \mathrm{C}$ in a reducing medium. This temperature makes possible attachment of the cutter and the hole. After cooling, the brazing toughens and the spring locking device is removed.

Cobalt determines the lowest threshold of PDC cutter temperature resistance. This temperature threshold is substantially lower than the temperature resistance of natural diamonds. Cobalt serves as a graphite solvent and catalyst for the conversion of graphite and the growth of diamond particles formed within the process of synthetic diamond production. If the PDC cutter is heated above $700{ }^{\circ} \mathrm{C}$, the cobalt again begins to act as a catalyst, but in this case, it stimulates the conversion of diamond crystals to graphite. Therefore, in order to avoid the risk of spontaneous graphitization, it is important to use the PDC cutter at temperatures below the critical temperatures.

In Ukraine, the technology of PDC drill bits was developed at the V.M. Bakul Institute for Superhard Materials of the National Academy of Sciences of Ukraine. However, technologies often do not meet the state-of-the-art requirements. The technology provides the brazing of the PDC plate and hard alloy holders with the blade that does not allow controlling the temperature of the diamond layer. 
Fig. 7. Bi-directional inductor placement diagram and temperature distribution in the brazing area for one and two loops [102]

In addition, only the surface layer is heated, but not the entire metal within the induction brazing. Besides, the one-loop induction technology used for successive brazing of PDC cutters to blades is rather outdated. This technology forms uneven temperature field in the blade within the next PDC cutter brazing as well as re-heating the already brazed PDC cutter when braze the

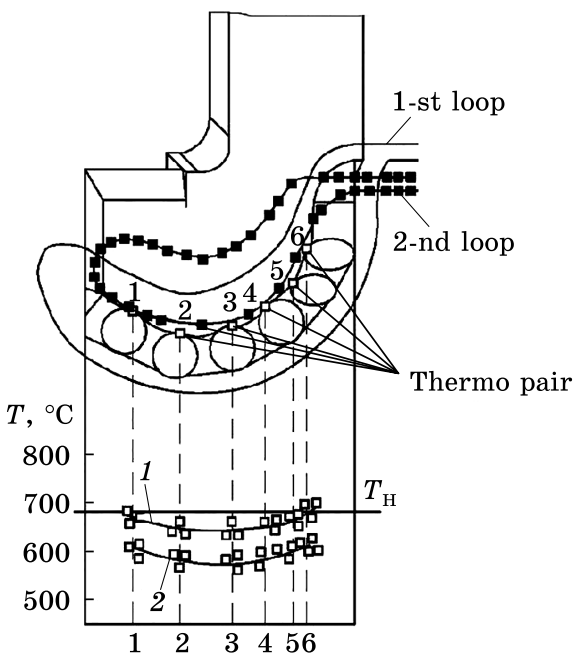
next one. In addition, induction heating is sometimes combined with gas-flame (surface) heating, which creates the risk of direct contact of the diamond layer with the flame of the burner.

The article [102] presents the developed a two-loop inductor technology. A two-loop inductor is introduced into the working area of the blades with cutters (Fig. 7) and provides a uniform temperature field in the heating region of the cutters. The size and shape of the inductor was determined experimentally. In this case, the value of the current in each of the loops depends on the distance to the cutter and geometric dimensions of the loops. This technology in some cases is used to achieve the desired heating temperature of the details of various sections and sizes.

The first loop of the inductor heats the work zone of the bit to a temperature of $680-700{ }^{\circ} \mathrm{C}$, and the second loop acts as pre-heating from 580 to $600{ }^{\circ} \mathrm{C}$. In this case, surface and deep heating are used for uniform heating of the bit body in the desired area without overheating of individual sections by heating duration increasing and specific power decreasing. The high-frequency heating make possible to braze all the cutters simultaneously to the blade. The PDC plate is heated at high temperature for a minimum time and retains the necessary technological properties during operation. The temperature field in the heated area is aligned throughout the blade; the temperature is from about 680 to $700{ }^{\circ} \mathrm{C}$.

The method of layered structure thermal state studying [103] can also be used to simulate PDC drill bit plate-rock frictional interaction.

At the same time, according to another method of PDC cutter attachment [92], cutters are placed in inserts made of plastic metal and then are pressed into the blades. The inserts have longitudinal grooves on the outer surface providing better adhesion. The cutter pressing into the metal inserts reduces the compression stress and increases the ac- 


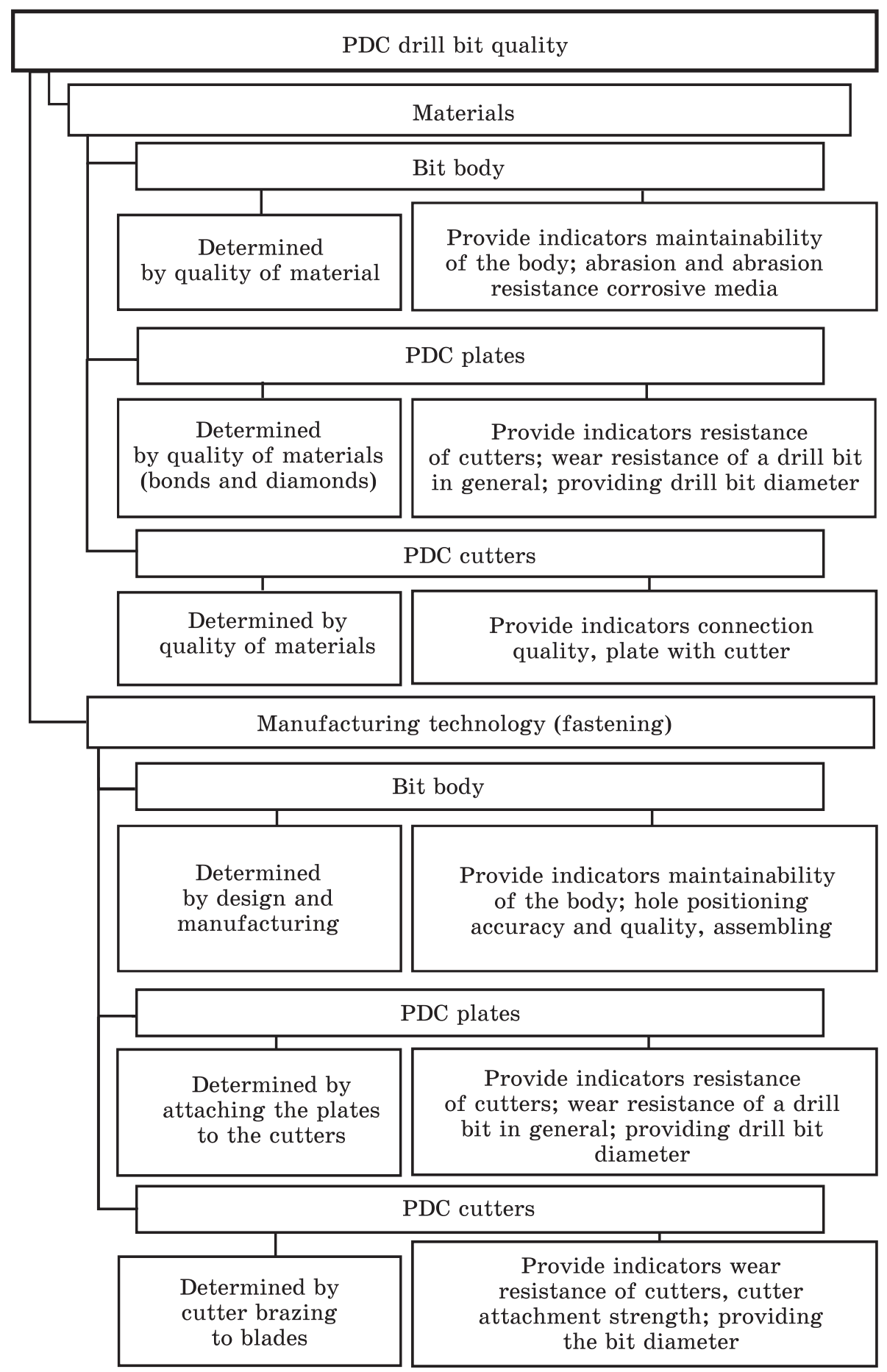

Fig. 8. Drill bit quality formation diagram technology (developed by the authors) 
tual contact surface. Bending stresses (i.e., compression and tensile) deform metal inserts and decrease the total stresses. This fastening method is carried out without heating and brazing. However, this method does not make possible to repair PDC cutters by their rotation and reinstallation with the unworn side.

The work [93] proposed to place cutters in plastic metal inserts in the blades. Attachment of the PDC cutter is performed using a pair of forcefully mounted conical retaining bushings.

So, summarizing the above, we can conclude:

- brazing is a modern way of fastening the cutters to the blades;

- the main problem with soldering is providing the proper temperature mode;

- the brazier must be able to replace the cutters along with their reliability within operation.

\section{Conclusions}

Drilling equipment life and reliability are determined by many factors, the main of them are technological ones. The rational choice of metals is the basis for providing rock destructive tool quality and reliability. This way drilling tool manufacturing technology is based on the physical-metallurgy approach, and drill bit quality depends on the structure, nature and the physical and mechanical properties of metals and alloys and is determined at each of the technological stages. Figure 8 shows the developed model of drill bit quality.

PDC drill bit design consists of the body with blades and blazed cutters, respectively; the technological consists of the following main stages:

- manufacturing of the nipple, base and blade;

- manufacturing of PDC cutters;

- brazing cutters into blades;

- assembling of the bit (blades-body-nipple);

- further treatment of the bit body (threading) [104].

The technology comprises the following technological stages to provide drill bit quality: workpieces manufacturing, rough and semi-rough machining, chemical-thermal treatment, coating of the body, assembly of the bit as a whole, quality control. It should be noted that quality providing and cost saving are the main aspects of all stages of drill bit manufacturing and operating.

Drill bit quality is a complex indicator, which is determined by both the materials and the technology of production of individual chisel elements.

Drill bit quality assurance begins at the design stage. All modern approaches to technology improving are determined by the structure and physical and mechanical properties of metals, in particular, metals and alloys used for PDC drill bit manufacturing (powder agglomeration 
technology or welding for body manufacturing, various types of coatings, PDC cutter soldering, thread machining).

The drill bit design is an aggregate of interconnected assemblies, parts, elements and materials that function in complex operating conditions. Under these conditions, the quality of individual elements of the structure determines the decisive influence on the efficiency of the drill bit as a whole. Therefore, it is important not only to find the perfect technology for drill bits and their parts manufacturing but also to make a reasonable choice of materials that provide technological, operational and economic indicators of the work [81].

\section{REFERENCES}

1. Energy Strategy of Ukraine for the Period until 2035. Approved by the Cabinet of Ministers of Ukraine on August 15, 2017 No. 605-p (available at: http://mpe. $\mathrm{kmu} . g o v . u a / \mathrm{minugol} / \mathrm{control} / \mathrm{publish} /$ article?art_id=245234085) (in Ukrainian).

2. V.G. Neupokoev and A.A. Chernik, Chemical and Petroleum Engineering, 20, No. 9: 461 (1984). https://doi.org/10.1007/BF01166117

3. M. Yahiaoui, L. Gerbaud, J.-Y. Paris, J. Denape, and A. Dourfaye, Wear, 32, No. 1: 298 (2013). https://doi.org/10.1016/j.wear.2012.12.026

4. T.O. Pryhorovska, Machining Science and Technology, 21, No. 1: 37 (2017). https://doi.org/10.1080/10910344.2016.1260429

5. T.A. Pryhorovska and S.S. Chaplinskiy, Neftyanoye Khozyaystvo - Oil Industry, 1131, No. 1: 38 (2018) (in Russian). https://doi.org/10.24887/0028-2448-2017-1-38-41

6. T.O. Pryhorovska and S.S. Chaplinskyy, Naukovyi Visnyk Natsionalnoho Hirnychoho Universytetu, 39, No. 5: 39 (2014) (in Ukrainian).

7. A.A. Bedzir, I.P. Shatskii, and V.M. Shopa, International Applied Mechanics, 31, No. 5: 351 (1995). https://doi.org/10.1007/BF00846842

8. I.Yo. Popadyuk, I.P. Shats'kyi, V.M. Shopa, and A.S. Velychkovych, Journal of Mathematical Sciences, 215, No. 2: 243 (2016). https://doi.org/10.1007/s10958-016-2834-x

9. A. Velichkovich, T. Dalyak, and I. Petryk, Oil and Gas Science and Technology, 73, 2018043 (2018). https://doi.org/10.2516/ogst/2018043

10. V.M. Shopa, I.P. Shatskii, and I.I. Popadyuk, Soviet Engineering Research, 9, No. 3: 42 (1989).

11. V.M. Shopa, I.P. Shatskii, and A.S. Velichkovich, Neftyanoye Khozyaystvo Oil Industry, No. 3: 28 (1990).

12. S.V. Velichkovich, I.I. Popadyuk, I.P. Shatskii, and V.M. Shopa, Strength of Materials, 23, No. 3: 279 (1991). https://doi.org/10.1007/BF01194768

13. I. Shatskyi, I. Popadyuk, and A. Velychkovych, Springer Proceedings in Mathematics and Statistics, 249: 343 (2018). https://doi.org/10.1007/978-3-319-96601-4_31 
14. I.P. Shatskii and V.V. Perepichka, Journal of Applied Mechanics and Technical Physics, 54, No. 6: 1016 (2013). https://doi.org/10.1134/S0021894413060163

15. I. Shatskyi and V. Perepichka, Springer Proceedings in Mathematics and Statistics, 249: 335 (2018). https://doi.org/10.1007/978-3-319-96601-4_30

16. C.H. Cooley, P.E. Pastusek, and L.A. Sinor, SPE Annual Technical Conference and Exhibition, SPE-24586-MS (1992).

17. E.I. Kryzhanivs'kyi, V.P. Rudko, and I.P. Shats'kyi, Materials Science, 40, No. 4: 547 (2004). https://doi.org/10.1007/s11003-005-0076-z

18. I.P. Shats'kyi and A.B. Struk, Strength of Materials, 41, No. 5: 548 (2009). https://doi.org/10.1007/s11223-009-9165-9

19. A.S. Velychkovych, A.V. Andrusyak, T.O. Pryhorovska, and L.Y. Ropyak, Oil and Gas Science and Technology, 74: 2019039 (2019). https://doi.org/10.2516/ogst/2019039

20. I.P. Shats'kyi, O.M. Lyskanych, and V.A. Kornuta, Strength of Materials, 48, No. 3: 469 (2016). https://doi.org/10.1007/s11223-016-9786-8

21. G. Dong and P. Chen, Hindawi Publishing Corporation Shock and Vibration Shock and Vibration, 2016, No. 1: 1 (2016). https://doi.org/10.1155/2016/7418635

22. I.I. Vytvytskyi, M.V. Seniushkovych, and I.P. Shatskyi, Naukovyi Visnyk Natsionalnoho Hirnychoho Universytetu, 28, No. 5: 29 (2017).

23. I. Shatskyi, I. Vytvytskyi, M. Seniushkovych and A. Velychkovych, IOP Conf. Series: Materials Science and Engineering, 564, 012073 (2019). https://doi.org/10.1088/1757-899X/564/1/012073

24. I. Shatskyi, A. Velychkovych, I. Vytvytskyi, and M. Seniushkovych, Engineering Solid Mechanics, 7, No. 4: 355 (2019). https://doi.org/10.5267/j.esm.2019.6.002

25. M. Dutkiewicz, I. Gołębiowska, I. Shatskyi, V. Shopa, and A. Velychkovych, MATEC Web of Conferences, 178, 06010 (2018). https://doi.org/10.1051/matecconf/201817806010

26. A.S. Velichkovich, Chemical and Petroleum Engineering, 41, Nos. 7-8: 363 (2005). https://doi.org/10.1007/s10556-005-0121-7

27. A.S. Velichkovich, Chemical and Petroleum Engineering, 43, Nos. 7-8: 458 (2007). https://doi.org/10.1007/s10556-007-0081-1

28. A.S. Velichkovich, I.I. Popadyuk, and V.M. Shopa, Chemical and Petroleum Engineering, 46, Nos. 9-10: 518 (2011). https://doi.org/10.1007/s10556-011-9370-9

29. I. Shatskyi, I. Popadyuk, and A. Velychkovych, 23rd International Conference on Engineering Mechanics (May 15-18, 2017, Svratka, Czech Republic) (Brno: Brno University of Technology, Faculty of Mechanical Engineering, Institute of Solid Mechanics, Mechatronics and Biomechanics: 2017), p. 870.

30. A.S. Velichkovich and T.M. Dalyak, Chemical and Petroleum Engineering, 51, No. 3: 188 (2015). https://doi.org/10.1007/s10556-015-0022-3

31. A. Velychkovych, I. Petryk, and L. Ropyak, Shock and Vibration, 2020: 3292713 (2020). https://doi.org/10.1155/2020/3292713

32. K.G. Levchuk, Metallofizika i Noveishie Tekhnologii, 40, No. 1: 45 (2018) (in Ukrainian). https://doi.org/10.15407/mfint.40.01.0045 
33. V. Moisyshyn and K. Levchuk, Oil and Gas Science and Technology, 72, No. 5: 27 (2017). https://doi.org/10.2516/ogst/2017024

34. K.G. Levchuk, SOCAR Proceedings, No. 2: 23 (2017). https://doi.org/10.5510/OGP20170200312

35. K.G. Levchuk, V.M. Moisyshyn, and I.V. Tsidylo, Metallofizika i Noveishie Tekhnologii, 38, No. 12: 1655 (2016) (in Ukrainian). https://doi.org/10.15407/mfint.38.12.1655

36. Yu.Yo. Striletskyy and V.A. Rovinskyy, Metallofizika i Noveishie Tekhnologii, 39, No. 10: 1377 (2017) (in Ukrainian). https://doi.org/10.15407/mfint.39.10.1377

37. O. Vlasiy, V. Mazurenko, L. Ropyak, and O. Rogal, Eastern-European Journal of Enterprise Technologies, 1, No. 7 (85): 25 (2017) (in Ukrainian). https://doi.org/10.15587/1729-4061.2017.65718

38. L. Ropyak, I. Schuliar, and O. Bohachenko, Eastern-European Journal of Enterprise Technologies, 1, No. 5 (79): 53 (2016) (in Ukrainian). https://doi.org/10.15587/1729-4061.2016.59850

39. O.M. Semegen, Z.M. Odosii, and V.V. Kustov, Strength of Materials, 46, No. 4: 575 (2014). https://doi.org/10.1007/s11223-014-9585-z

40. V.B. Tarelnyk, O.P. Gaponova, I.V. Konoplianchenko, and M.Ya. Dovzhyk, Metallofizika i Noveishie Tekhnologii, 39, No. 3: 363 (2017) (in Russian). https://doi.org/10.15407/mfint.39.03.0363

41. V.B. Tarelnyk, O.P. Gaponova, I.V. Konoplianchenko, and M.Ya. Dovzhyk, Metallofizika i Noveishie Tekhnologii, 38, No. 12: 1611 (2016) (in Russian). https://doi.org/10.15407/mfint.38.12.1611

42. V.M. Beresnev, Yu.M. Shabelnyk, N.I. Shumakova, U.S. Nyemchenko, and A.S. Manokhin, Journal of Nano- and Electronic Physics, 9, No. 4 (2017). https://doi.org/10.21272/jnep.9(4).04023

43. V.M. Nadutov, A.V. Proshak, S.Y. Makarenko, V.Y. Panarin, and M.Y. Svavil'nyj, Materialwissenschaft und Werkstoffechnik, 47, Nos. 2-3: 272 (2016). https://doi.org/10.1002/mawe.201600489

44. V.Ye. Panarin, M.Ye. Svavil'nyy, A.I. Khominych, M.V. Kindrachuk, and A.O. Kornienko, Journal of Nano- and Electronic Physics, 9, No. 6: 06023 (2017) (in Ukrainian). https://doi.org/10.21272/jnep.9(6).06023

45. I.Yu. Sagalianov, T.M. Radchenko, Yu.I. Prylutskyy, V.A. Tatarenko, and P. Szroeder, European Physical Journal B, 90, No. 6: 112 (2017). https://doi.org/10.1140/epjb/e2017-80091-x

46. S.I. Kryshtopa, D.Y. Petryna, I.M. Bogatchuk, I.B. Prun'ko, and V.M. Mel'nyk, Materials Science, 53, No. 3: 351 (2017). https://doi.org/10.1007/s11003-017-0082-y

47. L.S. Saakiyan, A.P. Efremov, and L.Ya. Ropyak, Zashchita Metallov, 25, No. 2: 185 (1989) (in Russian).

48. L.S. Saakiyan, A.P. Efremov, L.Ya. Ropyak, and A.V. Gorbatskii, Soviet Materials Science, 23, No. 3: 267 (1987). https://doi.org/10.1007/BF00720884

49. Y. Striletsyi, V. Rovinskiy, and O. Yevchuk, Eastern-European Journal of Enterprise Technologies, 3, No. 9 (81): 24 (2016) (in Ukrainian). https://doi.org/10.15587/1729-4061.2016.71969 
50. V.B. Tarelnyk, O.P. Gaponova, I.V. Konoplianchenko, V.A. Herasymenko, and N.S. Evtushenko, Metallofizika i Noveishie Tekhnologii, 40, No. 2: 235 (2018). https://doi.org/10.15407/mfint.40.02.023

51. M.A. Dolgov, N.A. Zubrets'ka, A.V. Buketov, and P.D. Stukhlyak, Strength of Materials, 44, No. 1: 81 (2012).

https://doi.org/10.1007/s11223-012-9352-y

52. N. Prokopiv, O. Kharchenko, E. Gevorkyan, and Y. Gutsalenko, Eastern-European Journal of Enterprise Technologies, 3, No. 12 (99): 17 (2019). https://doi.org/10.15587/1729-4061.2019.171805

53. M. Pashchenko, J. Jozwik, K. Dziedzic, M. Karolus, and I. Usidus, Materials Science, 52, No. 6: 834 (2017). https://doi.org/10.1007/s11003-017-0028-4.

54. I.M. Zin', R.S. Mardarevych, L.M. Bilyi, S.A. Kornii, and Z.A. Duryagina, Materials Science, 55: 284 (2019).

https://doi.org/10.1007/s11003-019-00301-3

55. A. Permyakov, S. Dobrotvorskiy, L. Dobrotvorskiy, Y. Basova, and M. Ivanova, Advances in Design, Simulation and Manufacturing. DSMIE 2018. Lecture Notes in Mechanical Engineering (Eds. V. Ivanov, Y. Rong, J. Trojanowska, J. Venus, O. Liaposhchenko, J. Zajac, I. Pavlenko, M. Edl, and D. Perakovic) (Cham: Springer: 2019), p. 135.

https://doi.org/10.1007/978-3-319-93587-4_15

56. I.P. Shatskyi, L.Ya. Ropyak, and M.V. Makoviichuk, Strength of Materials, 48, No. 5: 726 (2016). https://doi.org/10.1007/s11223-016-9817-5

57. L.Ya. Ropyak, I.P. Shatskyi, and M.V. Makoviichuk, Metallofizika i Noveishie Tekhnologii, 39, No. 4: 517 (2017). https://doi.org/10.15407/mfint.39.04.0517

58. N.A. Dolgov, Strength of Materials, 48, No. 5: 658 (2016). https://doi.org/10.1007/s11223-016-9809-5

59. I.P. Shats'kyi, M.V. Makoviichuk, Materials Science, 39, No. 3: 371 (2003). https://doi.org/10.1023/B:MASC.0000010742.15838.44

60. L.Ya. Ropyak, I.P. Shatskyi, and M.V. Makoviichuk, Metallofizika i Noveishie Tekhnologii, 41, No. 5: 657 (2019). https://doi.org/10.15407/mfint.41.05.0647

61. L. Ropyak and V. Ostapovych, Eastern-European Journal of Enterprise Technologies, 1, No. 2 (5): 50 (2016).

https://doi.org/10.15587/1729-4061.2016.65719

62. I.P. Shatskii, Journal of Applied Mechanics and Technical Physics, 30, No. 5: 828 (1989).

https://doi.org/10.1007/BF00851435

63. I.P. Shats'kii, Journal of Soviet Mathematics, 67, No. 5: 3355 (1993). https://doi.org/10.1007/BF01097747

64. I.P. Shatskii, Journal of Soviet Mathematics, 76, No. 3: 2370 (1995). https://doi.org/10.1007/BF02362900

65. I.P. Shats'kyi, Materials Science, 41, No. 2: 186 (2005). https://doi.org/10.1007/s11003-005-0149-z

66. I.P. Shatskyi, M.V. Makoviichuk, and A.B. Shcherbii, Proceedings of the 11th International Conference on Shell Structures: Theory and Applications, SSTA 2017, 4: 165 (2018). https://doi.org/10.1201/9781315166605-34

67. I.P. Shats'kyi, M.V. Makoviichuk, and A.B. Shcherbii, Journal of Mathematical Sciences, 238, No. 2: 165 (2019).

https://doi.org/10.1007/s10958-019-04226-9 
68. I. Shatskyi and I. Kurtash, Procedia Structural Integrity, 13: 1482 (2018). https://doi.org/10.1016/j.prostr.2018.12.305

69. V.V. Panasyuk, V.I. Marukha, and V.P. Sylovanyuk, Injection Technologies for the Repair of Damaged Concrete Structures (Dordrecht: Springer: 2014). https://doi.org/10.1007/978-94-007-7908-2

70. V.P. Sylovanyuk and R.Ya. Yukhim, Strength of Materials, 43, No. 1: 33 (2011). https://doi.org/10.1007/s11223-011-9265-1

71. I.P. Shats'kyi, Materials Science, 51, No.3: 322 (2015). https://doi.org/10.1007/s11003-015-9845-5

72. I.P. Shatskyi, V.V. Perepichka, and L.Ya. Ropyak, Metallofizika i Noveishie Tekhnologii, 42, No. 1: 69 (2020). https://doi.org/10.15407/mfint.42.01.0069

73. V.V. Kukhar and O.V. Vasylevskyi, Metallurgical and Mining Industry, No. 3: 71 (2014).

74. V.V. Kukhar, Metallurgical and Mining Industry, No. 6: 122 (2015).

75. V. Kukhar, V. Burko, A. Prysiazhnyi, E. Balalayeva, and M. Nahnibeda, EastEuropean Journal of Enterprise Technology, 3, No. 7 (81): 53 (2016). https://doi.org/10.15587/1729-4061.2016.72063

76. Materials of the Baker Hudges' site: https://www.bakerhughes.com.

77. A.G. Bogachenko, Yu.P. Linenko-Mel'nikov, and V.I. Mel'nik, Porodorazrushayushchiy i Metalloobrabatyvayushchiy Instrument. Tekhnika i Tekhnologiya Ego Primeneniya: Sbornik Nauchnykh Trudov, No. 12: 69 (2000) (in Russian).

78. M.Z. Khostikoev and A.N. Makhnenko, Gornyy Informatsionno-Analiticheskiy Byulleten', 322, No. 4: (2011) (in Russian).

79. M.V. Maysuradze, M.A. Ryzhkov, Yu.V. Yudin, and O.A. Surnaeva, Proc. XV Int. Scientific and Technical Ural School-Seminar of Metal Scientists-Young Scientists (December 8-12, 2014, Ekaterinburg) (Ekaterinburg: 2014), p. 325 (in Russian).

80. V.Y. Buhakov and A.Y. Laptev, Izvestyia VUZov. Chernaya Metallurgiya, 60, No. 1: 36 (2017) (in Russian).

81. J.A. Oxford, J.W. Eason, R.H. Smith, J.H. Stevens, and N.J. Lyons, Bore Bit for Rotor Drilling and Procedure for Its Fabrication: Patent RU2412326, MKI E21B10/00, B22F7/06 (2011) (in Russian).

82. A.N. Zhuravlev and M.A. Borisov, Izvestiya Tomskogo Politekhnicheskogo Universiteta, 311, No. 2: 27 (2007) (in Russian).

83. B.V. Stefaniv, Automatic Welding, No. 9: 29 (2016) (in Russian). https://doi.org/10.15407/as2016.09.05

84. A.F. Salenko, A.N. Fedot'ev, L.P. Fedot'eva, and A.M. Mana, Scientific Bulletin of National Mining University, 6: 48 (2015) (in Ukrainian).

85. K.T. Kembaiyan, M.K. Keshavan, A.C. White, and B.A. White, Layered Hardfacing, Durable Hardfacing for Drill Bits: Patent US7770672B2, MKI, E21B 10/46, C23C 30/00 (2010).

86. V.V. Knysh, B.N. Mordyuk, G.I. Prokopenko, and S.A. Solovey, Metallofizika i Noveishie Tekhnologii, 41, No. 12: 1631 (2019). https://doi.org/10.15407/mfint.41.12.1631

87. R.M. Bogomolov, A.V. Kinyaev, S.M. Krylov, A.M. Grinev, D.R. Yamanaev, and M.I. Starygin, Almaznoe Doloto s Mekhanicheskim Krepleniem Reztsov [Diamond Drill Bit with Mechanical Fastening of Cutters]: Patent RU2536901, MKI 2536901, E21C35/197, E21B10/573 (2013) (in Russian).

88. M.S. Ostrovskiy, V.U. Mnatsakanyan, and V.A. Timiryazev, Programmirovanie Obrabotki Detaley Gornykh Mashin na Stankakhs ChPU: Uchebnoe Posobie [Pro- 
gramming the Processing of Parts of Mining Machines on CNC Machines: Training Manual] (Moscow: Izd-vo 'Gornaya Kniga': 2009) (in Russian).

89. V.G. Panchuk, L.Ya. Rop'yak, and O.R. Onis'ko, Rizets' dlya Narizannya Zovnishnyoyi Trykutnoyi Tsylindrychnoyi Narizi [Cutter for External Cylindrical Thread Vutting]: Patent UA109077C2, MKI B23B 27/06 (2015) (in Ukrainian).

90. M.D. Dennis and P.D. Gigl, Composite Compact of Interleaved Polycrystalline Particles and Cemented Carbide Masses: Patent US4255165A, MKI B227/06 (1978).

91. S.S. Vagarali, Method for Producing Cubic Boron Nitride Using Melamine as a Catalyst: Patent US5869015A, MKI, C04B, 35/5831 (1998).

92. A.L. Maystrenko, Formirovanie Struktury Kompozitsionnykh Almazosoderzhashchikh Materialov v Tekhnologicheskikh Protsessakh [Formation of Structure of Composite Diamond Materials in Technological Processes] (Kyiv: Naukova Dumka: 2014) (in Russian).

93. T. Nakai, Sh. Yazu, and A. Hara, Compound Sintered Compact for Use in a Tool and the Method for Producing the Same: Patent US4403015A, MKI, B22F 3/4 (1983).

94. Plastyny Almazno-Tverdosplavni dlya Rizal'nogo Instrumentu, TU 88 Ukrainy: 90.1244-91 (Kyiv: V.M. Bakul Institute for Superhard Materials of the AS of Ukraine: 1991) (in Ukrainian).

95. E.E. Ashkinazi, V.G. Ral'chenko, V.I. Konov, A.A. Shul'zhenko, A.N. Sokolov, and V.G. Gargin, Sverkhtverdyy Material [Superhard Material]: Patent RU2066729, MKI E21 V10/46 (1996) (in Russian).

96. N.V. Novikov, Yu.I. Nikitin, B.A. Uryukov, V.A. Manzhar, V.G. Poltoratskiy, A.A. Shul'zhenko, V.G. Gargin, and S.M. Uman, Sposob Izgotovleniya Almazno-Tverdosplavnykh Plastin [A method of Manufacturing of Diamond Carbide Plates]: Patent SU1566660 A1, MKI B24D 11/00 (1988) (in Russian).

97. Y. Shen, Y. Zhang, S. Yuang, and M. Keshavan, Polycrystalline Diamond Composites: Patent Application US20080073126A1, MKI E21B, 10/567 (2015).

98. C. Sheridan, Aggregate Abrasive Grains for Abrading or Cutting Tools Production: Patent Application US20110056142A1, MKI B24D3/008 (2013).

99. S. Middlemiss, J. Belnap, N. Mourik, T. Oldham, and A. Griffo, Thermally Stable Ultra-Hard Material Compact Construction: Patent Application 20060266558, MKI B24D 11/00 (2011).

100. Y. Shen, Y. Zhang, S. Yuang, and M. Keshavan, Polycrystalline Diamond Composites: Patent Application US20080073126A1, MPK E21B, 10/567 (2015).

101. V.T. Dmitriev, G.A. Boyarskikh, D.S. Dmitriev, I.G. Boyarskikh, and V.V. Murashov, Sposob Krepleniya Porodorazrushayushchikh Vstavok Burovogo Instrumenta i Rabochikh Organov Prokhodcheskikh Mashin [The Method of Fastening Rock-Cutting Inserts of Drilling Tools and Working Bodies of Tunnelling Machines]: Patent RU2477780, MKI E21V 10/573, E21S 35/197 (2009) (in Russian).

102. B.V. Stefaniv, Automatic Welding, No. 8: 50 (2013) (in Russian).

103. N. Volchenko, A. Volchenko, D. Volchenko, P. Poliakov, V. Malyk, D. Zhuravliov, V. Vytvytskyi, and P. Krasin, Eastern-European Journal of Enterprise Technologies, 1, No. 5 (97): 47 (2019).

https://doi.org/10.15587/1729-4061.2019.154712

104. V. Kopei, O. Onysko, and V. Panchuk, Advances in Design, Simulation and Manufacturing II. DSMIE 2019. Lecture Notes in Mechanical Engineering. 
(Eds. V. Ivanov, J. Trojanowska, J. Machado, O. Liaposhchenko, J. Zajac, I. Pavlenko, M. Edl, and D. Perakovic) (Cham: Springer: 2020), p. 149. https://doi.org/10.1007/978-3-030-22365-6_15

Received 24.02.2020;

in final version, 17.04.2020

\author{
Л.Я. Роп'як ${ }^{1}$, Т.О. Пригоровська ${ }^{1}$, К.Г. Левчук ${ }^{2}$ \\ ${ }^{1}$ Івано-Франківський національний технічний університет нафти і газу, \\ вул. Карпатська, 15, \\ 07600 Івано-Франківськ, Україна \\ ${ }^{2}$ Інститут металофізики ім. Г.В. Курдюмова НАН України, \\ бульв. Академіка Вернадського, 36, \\ 03142 Київ, Україна
}

\title{
АНАЛІЗ МАТЕРІАЛІВ І СУЧАСНИХ ТЕХНОЛОГІЙ ДЛЯ ВИГОТОВЛЕННЯ СВЕРДЕЛ, ОСНАЩЕНИХ КОРОНКАМИ, АРМОВАНИМИ ПОЛІКРИСТАЛІЧНИМИ СИНТЕТИЧНИМИ ДІАМАНТАМИ
}

3 метою залучення ширшого кола науковців до пошуку нових та удосконалення наявних технологічних процесів виготовлення бурильних доліт залежно від металів, що використовуються, способів формування точності й якості їхніх робочих поверхонь проведено огляд та аналіз технологічних систем механічного оброблення та наявних технічних засобів. Виконано огляд робіт, де розглянуто вплив механофізичних характеристик, властивостей, структури, а також сучасних технологій, інструментів і технічних засобів, проаналізовано основні тенденції та відмінності у технологіях, визначені металами, які застосовують. Показано, що металознавчий підхід до питань проєктування бурильних інструментів $\mathrm{\epsilon}$ основним шляхом для істотного підвищення їхніх експлуатаційних властивостей; крім цього, дослідження умов термодинамічної рівноваги та характеру перебігу в металевих матеріалах різних процесів під час виготовлення бурильних доліт забезпечать їхні високі експлуатаційні показники. Побудовано схему формування якості бурильного долота, згідно з якою якість долота є комплексним показником і визначена як металами, так і технологією виготовлення окремих елементів доліт. Показано, що до основних технологічних етапів, на яких формується якість долота, належать: виробництво заготовок, чорнове та напівчистове механічне оброблення різанням деталей, хіміко-термічне оброблення, покриття корпусу, викінчувальне механічне оброблення різанням, прилютовування різців, складання долота в цілому. Встановлено, що вибір металу для виготовлення бурильного долота визначає відмінності не тільки технологічні, але й конструктивні.

Ключові слова: бурильне долото РDC, якість, технологія, метал, зварювання, лиття, корпус, різець. 
Л.Я. Ропяк ${ }^{1}$, Т.А. Пригоровская ${ }^{1}$, К.Г. Левчук ${ }^{2}$

${ }^{1}$ Ивано-Франковский национальный технический университет нефти и газа, ул. Карпатская, 15, 07600 Ивано-Франковск, Украина

${ }^{2}$ Институт металлофизики им. Г.В. Курдюмова НАН Украины, бульв. Академика Вернадского, 36, 03142 Киев, Украина

\section{АНАЛИЗ МАТЕРИАЛОВ И СОВРЕМЕННЫХ ТЕХНОЛОГИЙ ДЛЯ ИЗГОТОВЛЕНИЯ СВЁРЛ, ОСНАЩЁННЫХ КОРОНКАМИ, АРМИРОВАННЫМИ ПОЛИКРИСТАЛЛИЧЕСКИМИ СИНТЕТИЧЕСКИМИ АЛМАЗАМИ}

$\mathrm{C}$ целью привлечения более широкого круга учёных к поиску новых и усовершенствованию имеющихся технологических процессов изготовления буровых долот в зависимости от используемых материалов, способов формирования точности и качества их рабочих поверхностей проведён обзор и анализ технологических систем механической обработки и имеющихся технических средств. Выполнен обзор работ, где рассмотрено влияние механико-физических характеристик, свойств, структуры, а также современных технологий, инструментов и технических средств, проанализированы основные тенденции и различия в технологиях, которые определяются используемыми материалами. Показано, что металловедческий подход к вопросам проектирования буровых инструментов является основным путём для существенного повышения их эксплуатационных свойств; кроме этого, исследования условий термодинамического равновесия и характера протекания в металлических материалах различных процессов при изготовлении буровых долот обеспечат их высокие эксплуатационные показатели. Построена схема формирования качества бурового долота, согласно которой качество долота является комплексным показателем и определяется как материалами, так и технологией изготовления отдельных элементов долот. Показано, что основными технологическими этапами, на которых формируется качество долота, является производство заготовок, черновая и получистовая механическая обработка резанием деталей, химико-термическая обработка, покрытие корпуса, доводочная механическая обработка резанием, припайки резцов, сборка долота в целом. Установлено, что различия в применяемых материалах определяют различия не только в технологии, но и в конструкции бурового долота.

Ключевые слова: буровое долото PDC, качество, технология, металл, сварка, литьё, корпус, резец. 